\title{
INTERPRETATION OF ZAHIRIDDIN MUHAMMAD BABUR'S IMAGE IN UZBEK AND WORLD LITERATURE
}

\author{
Khayrullayeva Kamola Ravshanovna \\ English language teacher at Bukhara State Medical Institute named after Abu Ali Ibn Sino
}

Article DOI: https://doi.org/10.36713/epra4156

\begin{abstract}
This article researches on interpretation of Zahiriddin Muhammad Babur's image in world and Uzbek literature. During the investigations literary works by authors of these nations are widely analyzed. Description of Babur's image as a great king and commander, an unmatched writer and poet, a true expert in the arts, gardening and construction are displayed in a comparative way including several samples of author's opinions about Zahiriddin Muhammad.
\end{abstract}

KEY WORDS: Zahiriddin Muhammad Babur, turks, mongols, king, commander, poet, writer, composer, music writer, gardener, constructor.

\section{INTRODUCTION}

When we look through the human history, we can see that from past to present, many kings and commanders, poets and writers, musicians and craftsmen have left their mark in world history. But it is Zahiriddin Muhammad Babur who combines all of the above qualities, leaving a lasting mark on the history of Central Asia, Afghanistan and India. It is also worth noting that Zahiriddin Muhammad is interpreted in the historical literature of Uzbekistan and the world as a king with a complex destiny, a highly educated scholar, a priceless writer in poetry and prose.

The main purpose of writing this article is the interpretation of Babur's image in Uzbek and world literature, as well as the analysis of works dedicated to the great person.

Known as the famous writer Zahiriddin was born in Ferghana region on February 14, 1483. He was the son of Timurid Omar Sheikh Mirzo. However, Indian writer S.M.Jaffar indicated some misconception in his work "The Mughal Empire from Babar to Aurangzeb" that Zahiriddin was born on February 24, 1483.
According to the information given by Babur himself, his father was the son of Abu Said Mirzo, and he was a descendant of Sultan Miranshah, the third son of Amir Temur. There are numerous references that Bobur was the descendant of the Mongols. The main reason for this data that Zahiriddin's mother, Kutlug Nigor Khanum was the second daughter of the Honorable Yunus Khan, and Yunus Khan was descendant of Chigatai Khan who was the second son of the Mongol invader Chingiz Khan. (S.M. Edwardes et al., 1926)

Babur inherited his qualities from his ancestors, Chingiz Khan and Amir Temur, who were brutal and cruel invaders, who plagued various disasters and tribulations in Central Asia. In particular, the courage and bravery of the Turks, the infinite power of the Moguls were absorbed in Bobur's blood. (S.M. Edwardes et al., 1926). From this information, we can see that foreign writers, in particular Stephen Meredith Edwardes was not very positive attitude towards the personality of Babur's great-great-grandfather, Amir Temur, and Genghis Khan. However, writer emphasizes that despite being descendants of Genghis Khan, Zahiriddin inherited only noble qualities from his ancestors. 


\section{EPRA International Journal of Research and Development (IJRD)}

After the birth, newborn baby was given the Arabic name "Zahiriddin", which means "Defender of the Faith." But his grandparents Yunus Khan and Eson Davlat Begim who were unable to pronounce the Arabic name correctly, called their grandchild like "Babur", meaning "Little Tiger". (H. Lamb et al., 1961)

After gaining the reign of father in 1494, Babur was forced to fight with his own uncles for the throne. As a result, Zahiriddin lost his lands for the sake of Shaibanids and then in 1504 "Tiger" established his new country in Khurasan and continued his reign as a king. Soon Kandahar and Herat lands were also conquered.

Subsequently, while continuing his rule in Khurasan, Zahiriddin began to think of conquering India. In his youth, Babur had read and heard about the triumphal procession of his ancestor Temur to India. At that time Babur himself was planning to conquer the fertile fields, rich nature and vast plains of India. However, he could not fully state the reason why Babur put his family and his army in danger of occupying the territory of North India. Despite the fact that royal power was in the blood of Babur, he was more commonly known as a "born traveler" and his character determined his fate. (H. Lamb et al., 1961)

Zahiriddin conducted military actions towards India for 5 times during 1519-1526. As the famous writer Harold Lamb wrote in his book, "The First Reign of the Great Mughals in India began on Friday, April 27, 1526 and Zahiriddin Muhammad Babur's name was declared as "King of Kabul and India" at the mosque during the religious ceremony".

In order to establish his rule in other parts of India, Babur marched against the ruler Ibrahim Lodi. Ibrahim's humiliation and mismanagement had wiped out the whole nation. Even his close relatives were on Zahiriddin's side. Zahiriddin worked hard at planning every military action and was able to achieve many of his goals. This is evidenced by the fact that he could take advantage of this situation, Babur defeated the weak 12,000 men army of Ibrahim Lodi with his well-trained, strong army, including only 100,000 men. After that time, Babur became the sole ruler of the whole North India. (S.M. Jaffar et al., 1936)

In 1530, Babur decided to inherit his throne to his elder son Humayun, and he intended to spend the rest of his life with gardening. But in the summer of 1530, Humayun fell ill with fever. Babur then consulted with world-renowned healers to cure his son, and they offered him to give a precious brilliant "Kohinur" in exchange for Humayun's life. Although Zahiriddin refused because his intention was to save his son's life in exchange for his own life, which was more precious than anything else. (S.M. Edwardes et al., 1926) First of all, Zahiriddin went around the bed of his son three times and exclaimed: "O Allah! If life is to be taken instead of life, I - who is, Babur - will give my life and everything to my son Humayun." (H. Lamb et al., 1961)

After that incident, Humayun's condition began to improve, and Babur's health, on the contrary, began to deteriorate. Great king struggled against serious illness for more than three months. One day, Babur summoned his son Humayun and told him: "If God grants you the throne, do not kill your brothers, don't hurt them, but always keep them close to your wings. " (F. Grenard et al., 1931) From his words we can understand that he took care of not only Humayun but also all of his other children.

On December 26, 1530, the great king and commander Zahiriddin Muhammad Babur, the incomparable writer and poet, passed away this world forever. He himself bequeathed his burial at the "Aram Bagh" garden in Kabul, but according to the English writer Harold Lamb's "Babur The Tiger: First of the Great Moguls", Babur was buried in the garden of Agra, which was later called like "Taj Mahal". Later, the tomb of the great commander was decorated as a sacred place, and future generations used to come for visit his grandfather's grave. His grave remained there for 9 years. Babur's tomb was then moved to "Aram Bagh" garden which was created by him during his lifetime in Kabul.

\section{Interpretation of Zahiriddin Muhammad Babur's image as a great king and commander}

As mentioned earlier, Babur has left a mark in history as a king, commander, writer and poet, musician and gardener, and architect and painter. The autobiographical work of the Babur "Baburnama" and masterpieces of Uzbek and world literature which are devoted to his life and work can be acknowledged.

Zahiriddin Muhammad, who ruled Kabul from 1504-1526, established a centralized, strong state. He did extensive work on improving the country. He ordered to build big markets. It boosted both domestic and foreign trade. The release of new canals was a major factor in the regulation of dams. "Tiger" expanded the cultivated area, created new parks. He built monuments based on oriental architectural traditions. As a result, this contributed to the spiritual and economic value of the people. (Zokirjon Mashrabov et al., 1997)

According to Jawaharlal Nehru's "The Discovery of India", one of the most important reasons for Babur's easy and quick access to the Indian land was that he used new and improved artillery that had not yet existed in India. The use of new weapons brought success against enemies. From this information, it is clear that, first of all, Zahiriddin started every march on the basis of careful preparation and a well-thought-out military plan. And 


\section{EPRA International Journal of Research and Development (IJRD)}

that was a victory factor in his main battles. With the arrival of Babur to the Indian land, the most prosperous period in Indian history began. At the time, the common people were devastated by the mismanagement of Ibrahim Lodi. Under the rule of Mongols, India reached its peak of development. (J. Nehru et al., 1985)

With the entry of the Timurids, the state ownership of the state ceased. The Turks and the Safavid dynasty also refused to divide the state into shares. However, the Baburids introduced a better system of government in the Indian subcontinent than their predecessors. Although the Baburid government was similar to the Indian system, it still had the effect on compact management. (Zokirjon Mashrabov et al., 1997)

\section{Description of Babur's human qualities as a person, husband and father}

Although Zahiriddin was a great king and commander, he was, above all, a loving father and beloved companion in family circle. Now let's talk about his character traits.

According to the information given by great historian Muhammad Haydar Rashidiy, at an early age Zahiriddin Muhammad had innumerable virtues and was different from others with his bravery and plight. One of Babur's most important qualities is his sense of loyalty to both generations. He has always been generous and respectful towards his brothers.

And now let's learn about "Tiger's" life in marriage. During his 48 years of life, Babur was married seven times and became father of 17 children, but 8 of them died when they were only infants. Mohim Begim was one of Zahiriddin's favorite wives who gave birth to Babur's first son, Humoyun and his other four children. Another favourite one was Gulruh Begim who gave birth to 5 children of Babur. (S.M.Edwardes et al., 1926) According to sources, no women, especially their spouses, were never made to live like slaves in Zahiriddin's palace. Despite being a great king, Babur had a high respect towards his spouses who gave birth to his children and raised them.

As a father, Babur was very kind, thoughtful and caring. He was even ready to sacrifice his life for the life and future of his children. In summary, Babur is interpreted in Uzbek and world literature not only as king and commander, but also as an exemplary father.

\section{Zahiriddin Muhammad Babur's interpretation as an artist, naturalist and musician}

Although Zahiriddin Muhammad Babur, as a great king and commander, conducted several brutal battles and inflicted heavy attacks on his enemies, he had a very affectionate heart. This is evidenced by his admiration for attractive music and unparalleled art. Babur himself was a true music fan and composer of several samples of songs. He listened attentively to songs performed by artists at various events and gatherings, and did not intend to spend long periods of time with unacceptable works of art.

Babur founded dozens of gardens near Kabul, such as "Baghi Vafo", "Baghi Kalon", and "Ram Bagh" in Agra. He himself created and maintained garden in Kabul which were full with citrus fruits, pomegranates and oranges. At the "Ram Bagh" in Agra, he ordered to build dams, baths, chimneys, and planted roses and other types of flowers in the garden. Even after his death, his grave was settled in "Aram Bagh" in Kabul, which was founded by himself. (H. Lamb et al., 1961)

Despite being a young prince, he enjoyed travelling, visiting all the cities and villages of the Fergana Valley, Samarkand, Tashkent, Bukhara, Hissar, and Herat, and the mountains. As he was in Afghanistan, Iran, Pakistan and India, he wrote down valuable scientific information about those lads. At that time Babur tried to penetrate every sphere, such as composition, geology, nature, administrative division, mountains, water, valleys and the surrounding areas, where he lived, ruled, namely Andijan, Kabul, and Agra. It gives a great deal of insight into the world of simulations, and gives a clear view of the geological resources, geotectonic processes and seismology. (Zokirjon Mashrabov et al., 1997)

The famous Indian writer Jawaharlal Nehru, in his book "The Discovery of India" says that Zahiriddin ordered Agra to be the capital of the Mogul Empire and then he used the service of unimaginable Constantinople architects of that time in order to reconstruct it. In his comment J. Nehru gave a description to "the Great Commander" in this way: "Babur saw very few parts of India. Many changes took place after the Mongol invasion. At that time, the Indian population was at a higher level of culture and way of life than Afghans. The Moguls introduced the noble way of living. Babur was a true Renaissance prince, traveler, historian, art specialist and literary writer." Zahiriddin's greatest contribution to India was his introduction of gardening, construction of fountains, small waterfall structures, flowers and plants. (S.M. Edwardes et al., 1926)

"If Zahiriddin had lived longer, he would have proved himself as a great leader," writes S.M. Jaffar in his book "The Mughal Empire from Babar to Aurangzeb". From these considerations, we can conclude that by the people of India, Babur was regarded only as a literary scholar and poet, art historian, naturalist and construction expert. Although he was known as a great commander because of his courage during the conquest of the 


\section{EPRA International Journal of Research and Development (IJRD)}

Indian province, he was not interpreted in the image of the great king because he ruled the country for only a few years.

\section{Interpretation of Zahiriddin's image as an unmatched writer and poet}

First and foremost, while describing Zahiriddin as a writer, we must mention about the "Baburnama" written by him throughout his life, which is the autobiographical work of the great leader containing life story. However, the book was not given this name by Babur himself. The name "Baburnama" was given by later historians and writers. In some sources, the work is also called "Memories". The well-known writer Lane-Poole also describes Zahiriddin's creative work in the following way: "Babur's role in history is significant with his travel to India, but his role in literary studies is determined by his first actions in his book "Memoirs". After all, Babur was a true master of poetry and prose in Turkish."

The famous English writer Stephen Meredith describes "Baburnama" as follows: "Its main feature is its correctness. The "Baburnoma" contains only the truth. The truth, and again the truth, is not anything else."

By collecting all his lyrical poetry, Zahiriddin created the "Kabul devon" in 1519, and the "Indian devon" in 1528-1529. The total number of poems created by the great poet is 400,119 of them are in the ghazal genre and 231 in the rubai genre. He also co-authored the book "Mubayyin-iZakot", written in 1522 especially to his son Humayun Mirzo. There is given the data on which includes tax rate that what amount of taxes should be collected according to the level of population.(https://uz.wikipedia.org/wiki/Bobur)

Being a well-versed linguist, Zahiriddin created the book "Mukhtasar" dedicated to the science of "Aruz" in 1523-1526, and it now serves linguists as a great source in linguistics. Babur, who was also interested in translation, translated the Hodja Ahror's "Volidia" from Persian into Turkish.

In addition, there is information that Babur wrote books such as "Harb ishi" in order to share his knowledge, skills in the military field and "Musika ilmi" to contribute to the development of music, but these two cultural and spiritual heritage have not been preserved to this day.

\section{CONCLUSION}

In summing up we can say that by taking into account all his military campaigns, efforts to revive the empire of Timur, conquering Samarkand three times and establishing a new empire not only in Khurasan and but also in the Indian province with only a few soldiers, we are sure that it was justful to give Zahiriddin the nickname "Babur", meaning
"Tiger". It is also worth noting that despite many years of surrendering, he endured all sorts of adversities, lost his homeland, and lived in a life of long-sufferings.

Undoubtedly, we can see princes in Central Asia at a higher level than Babur, including Zahiriddin's grandsons Akbar, Aurangzeb and his two great ancestors, Genghis Khan and Amir Temur. But when we regard Babur's mental maturity and social goodness; his actions as a prince; love of writing letters, paintings; his interest in art, nature, construction and architecture; not anyone in Asia can replace him.

In conclusion, it is known from all abovementioned facts that Babur had endless knowledge in constructing buildings, analyzing natural resources, creating masterpieces in music, poetry and literature. Due to all of his qualities and features, Zahiriddin Muhammad Babur can be described as an incomparable person that we can rarely find anybody who can stay above him.

\section{USED LITERATURE}

1. Z.M.Bobur. (1989), "Boburnoma", Yulduzcha nashriyoti, Toshkent.

2. P.Qodirov. (2006), "Yulduzli tunlar", Sharq nashriyot-matbaa aksiyadorlik tahririyati, Toshkent, p.p: 543.

3. Qamchibek Kenja. (2000), "Hind sorig'a", Sharq matbaa nashriyoti, Toshkent, p.p.:352.

4. Zokirjon Mashrabov, Sobirjon Shokarimov. (1997), "Asrlarni bo'ylagan Bobur", Yozuvchi nashriyoti, Toshkent, p.p.:176.

5. A.S.Beveridge. (1970), "Babur-Nama" (Memoirs of Babur) Translation, Taj Offset Press, New Delhi, p.p.: 1040.

6. Fernand Grenard. (1931). "Baber first of the Moghuls", Thornton Butterworth Limited, London, p.p.: 272.

7. H.Lamb.(1961), "Babur The Tiger: First of the great Moguls", Doubleday and company inc, New York, p.p.: 351.

8. J.Nehru. (1985) "The discovery of India", New York: Oxford University Press, Oxford, p.p.: 237257.

9. S.M.Edwardes.(1926) "Babur: diarist and despot", London: A.M.Philpot LTD, Great Britain, p.p.: 162.

10. S.M.Jaffar. (1936) "The Mughal Empire from Babar to Aurangzeb", Ripon printing press, Peshawar, p.p.:9-32.

11. https://uz.wikipedia.org/wiki/Bobur 